\title{
The force awakens: metastatic dormant cancer cells
}

So-Yeon Park ${ }^{1,2}$ and Jeong-Seok Nam ${ }^{1,2}$

\begin{abstract}
Recurrent cancer that spreads to distant sites is the leading cause of disease-related death among cancer patients. Cancer cells are likely to disseminate during cancer progression, and some may enter dormancy, remaining viable but not increasing. These dormant cancer cells (DCCs) are rarely detectable with current diagnostic systems. Moreover, they can interpret homoeostatic signals from the microenvironment, thereby evading immune surveillance and chemotherapy. Eventually, DCCs can reawaken in response to signals, which are not yet fully understood, resulting in recurrence and metastasis. Therefore, understanding the biology of DCC reawakening is key to preventing metastasis. Over the last decade, a growing body of literature has revealed the mechanisms involved in cancer dormancy and reawakening. The cytotoxic activity of immune cells can cause cancer cells to enter a dormant state, and chronic inflammation can reactivate cancer proliferation at distant sites. Upon the binding of circulating DCCs to extracellular molecules, various signaling cascades are activated and reinitiate cell proliferation. In the present review, we attempt to consolidate the existing literature to provide a framework for the understanding of this crucial step in cancer progression.
\end{abstract}

\section{Introduction}

The primary treatment for cancer is the surgical removal of cancer cells, which is often combined with chemoradiotherapy to kill surgically inaccessible cancer cells throughout the body. However, even patients who are considered clinically free of cancer cells after initial treatment frequently relapse with distant metastasis. Such metastatic outgrowth rapidly becomes uncontrollable with chemoradiation and manages to seed additional metastatic colonies, resulting in the disruption of vital organ function. Although the clinical importance of metastasis is therefore apparent, its underlying mechanisms remain unclear.

Metastasis is considered a series of linear events, termed the invasion-metastasis cascade ${ }^{1}$. The initiation step of metastasis begins when cancer cells at the primary tumor

\footnotetext{
Correspondence: Jeong-Seok Nam (namje@gist.ac.kr)

${ }^{1}$ School of Life Sciences, Gwangju Institute of Science and Technology, Gwangju 61005, Republic of Korea

${ }^{2}$ Cell Logistics Research Center, Gwangju Institute of Science and Technology, Gwangju 61005, Republic of Korea
}

growth site foster basement membrane degradation and enter the underlying interstitial matrix ${ }^{2}$. During this process, cancer cells usually promote vascularization in tumor tissues to sculpt a permissive microenvironment for cancer cell proliferation and gain access to the bloodstream ${ }^{3}$. Once cancer cells successfully penetrate into the blood or lymphatic circulatory system, they can disseminate throughout the body. In circulation, cancer cells are likely to exhibit mitotic arrest through reversible G0-G1 arrest, termed quiescence, in which they remain viable but do not increase. These dormant cancer cells (DCCs) are more susceptible to antiproliferative drugs. More recently, these circulating DCCs have been shown to evade immune surveillance by expressing programmed death ligand 1 (PDL-1); thus, they can persist for an extended period ${ }^{4,5}$. At some point, DCCs reach distant organs and infiltrate into the stroma, although they cannot grow into macroscopic lesions until they escape dormancy. This period is termed "metastatic cancer dormancy" and occurs between initial therapy and metastatic relapse. Eventually, in response to microenvironmental 
cues, DCCs gain the ability to re-enter the cell cycle and adapt to their new microenvironment, thereby progressing to metastatic outgrowth. Therefore, understanding the biology of DCC reawakening is key to preventing metastasis.

A growing body of research has provided insight into the molecular mechanisms of cellular dormancy and reactivation. Central to these mechanisms is crosstalk between cancer cells and their microenvironment, which is affected by complex interactions between cancer cells and stromal cells and surrounding extracellular matrix (ECM) components, as well as host immunity. After a long period in the bloodstream, DCCs eventually reach distant organs and encounter a new composition of ECM produced from the local stromal cells. Then, the binding of membrane receptors on DCCs activates various signaling cascades, driving cell cycle promotion and breaking dormancy. Meanwhile, the host immune system initially acts as a tumor suppressor but eventually favors cancer progression and promotes metastatic outgrowth by reactivating DCCs. In the present review, we focused on these cellular and acellular factors that reawaken DCCs and contribute to metastasis.

\section{Primary molecular mechanisms underlying cancer cell dormancy}

An overwhelming amount of evidence supports the notion that extracellular signal-regulated kinase (ERK) activation has a determinant role in whether cancer cells will proliferate or enter a state of dormancy. Persistently proliferating cancer cells exhibit constitutive ERK activation, which permits Go-G1-S phase transition and cell division $^{6,7}$. During ERK-induced proliferation, a high level of p38 mitogen-activated protein kinase (p38) activity functions as an inhibitory regulator of ERK and prevents cell proliferation by inducing G0-G1 arrest or triggering senescence and apoptosis ${ }^{8-10}$. Indeed, a luciferase reporter system visualized the in vivo ERK and p38 MAPK activities and provided direct evidence of p38/ERK activity as an indicator of DCCs in various types of cancer, including breast cancer, prostate cancer, melanoma, and fibrosarcoma ${ }^{8}$. Cancer cells with $\mathrm{p} 38^{\text {low }} /$ ERK $^{\text {high }}$ activity were highly proliferative in vivo, whereas those with p3 $8^{\text {high }} /$ ERK $^{\text {low }}$ activity were incapable of proliferation without increased apoptosis, suggesting that they were dormant in vivo. Meanwhile, multiple pharmacological and genetic interventions that change the balance of $\mathrm{p} 38$ / ERK activity in favor of ERK were able to break in vivo dormancy and induce cancer growth. Thus, it seems that regulatory factors that can change the signaling balance between ERK and p38 activities have a profound influence on whether cancer cells grow or remain dormant ${ }^{11}$.

Transforming growth factor- $\beta 2$ (TGF- $\beta 2$ ) is secreted from bone marrow-derived cells and thus is relatively abundant. TGF- $\beta 2$ binds to its receptors, TGF- $\beta$ receptor-I (TGF- $\beta$-RI) and TGF- $\beta$-RIII, on cancer cell membranes and induces $\mathrm{p} 38^{\text {high }} / \mathrm{ERK}^{\mathrm{low}}$ signaling ${ }^{12}$. The subsequent activation of Smad1/5 increases the expression of DEC2/ SHARP1 and p27 and downregulates cyclin-dependent kinase 4 (CDK4), which collectively facilitates the transition into cellular quiescence ${ }^{12,13}$. The production of TGF- $\beta 1 / 2$ is increased during osteoblast differentiation, along with that of bone morphogenetic protein (BMP) family proteins. Both TGF- $\beta 1$ and BMP- $3 \mathrm{~b}$ induce cancer cell quiescence. TGF$\beta$-RIII participates in both TGF- $\beta 1$ - and BMP-3b-induced dormancy and activates the phosphorylation of retinoblastoma through p38 MAPK activation. On the other hand, in the lung, where stromal TGF- $\beta 2$ secretion is low, ERK activation is restored, and DCCs transition into a highly proliferative state, fueling multiorgan metastasis ${ }^{12}$. Therefore, upon the exit of DCCs from bone marrow, the lack of growth factors can shift the balance of p38 MAPK and ERK activities toward ERK activation, creating a permissive microenvironment for metastatic outgrowth.

The urokinase plasminogen activator (uPA) system has been implicated in a shift from cancer dormancy to proliferation by mediating EGFR signaling ${ }^{14}$. Numerous types of cells, including epithelial cells, immune cells, and fibroblasts, produce and secrete uPA. uPA binds to its receptor (UPAR) and initiates a proteolytic cascade, resulting in the conversion of plasminogen into plasmin ${ }^{15}$. Plasmin degrades a wide range of extracellular components through its proteolytic activity and activates other enzymatic proteins, such as metalloproteinases, thereby promoting cancer invasion. Independent of catalytic activity, the uPAR-uPA interaction leads to the activation of integrin and epidermal growth factor receptor (EGFR) signaling, which consecutively activates ERK $1 / 2$ and lowers p38 activities, promoting mitotic cascades ${ }^{8,16,17}$. However, DCCs have been reported to express a low level of uPAR; thus, they exhibit a low level of integrin and EGFR activation, resulting in a $\mathrm{p} 38^{\text {high }} /$ ERK $^{\text {low }}$ activity ratio $^{8}$. Additionally, $\mathrm{p} 38^{\text {high }} /$ ERK $^{\text {low }}$ facilitates G0-G1 arrest by regulating a variety of transcription factors (TFs), such as nuclear receptor subfamily 2 group $\mathrm{F}$ member 1 (NR2F1), basic helix-loop-helix protein 3 (BHLHB3 or DEC2), and cyclin-dependent kinase inhibitors (p27 and p21), and downregulates G1 exit-promoting TFs, such as FOXM1 and c-Jun ${ }^{18}$. Therefore, this combinatorial regulation of TFs by $\mathrm{p} 38^{\text {high }} / \mathrm{ERK}^{\text {low }}$ activity is responsible for the quiescence program in $\mathrm{DCCs}^{11}$.

Additional studies have suggested that high p38 activity is linked to the survival of DCCs and related to endoplasmic reticulum (ER) stress. High p38 activity inhibits Bax activation by increasing the expression of the ER chaperone $\mathrm{BiP} / \mathrm{Grp78}$, thereby rendering DCCs highly resistant to chemotherapy $^{19}$. The activating transcription factor $6 \alpha$ (ATF6 $\alpha$ ), which is translocated from the ER to the nucleus 
to serve as a TF upon ER stress, is persistently activated in DCCs in a p38-dependent manner ${ }^{20}$. ATF6 $\alpha$ transcriptionally induces Rheb, a small GTPase, and transduces survival signals such as mTOR and downstream S6K and S6RP phosphorylation. Knockdown of ATF6 $\alpha$ or Rheb by RNA interference was sufficient to induce apoptosis in DCCs and remove DCCs during their quiescent phase ${ }^{20}$. This suggests that high p38 activity causes growth arrest in DCCs and simultaneously may activate the dormancyspecific survival signaling pathways that enable DCCs to resist microenvironmental and genotoxic stress.

Furthermore, some kinds of stroma-derived ligands are known to induce cancer cell dormancy in multiple types of cancer. For example, growth arrest-specific protein 6 (GAS6) has been shown to induce dormancy in several kinds of cancer cells that infiltrate the bone marrow. GAS6 is known to bind to the Tyro3, Axl, and Mer (TAM) family of receptor tyrosine kinases, thereby activating multiple downstream signaling pathways, including mitogenactivated protein kinase (MAPK) and phosphoinositide 3kinase (PI3K)/Akt pathways ${ }^{21}$. In particular, GAS6 promotes the transition of cancer cells into DCCs in the bone marrow. Mechanistically, osteoblasts secrete GAS6 upon their contact with leukemia cells, and the binding of GAS6 to Mer on the surface of leukemia cells facilitates the entry of leukemia cells into G0/G1 arrest ${ }^{22}$. Similarly, in bone marrow, GAS6 from osteoblasts activates TAM family receptors on prostate cancer cells and switches on dormancy in proliferative cancer cells ${ }^{23}$. Additionally, BMP7, produced from bone stromal cells, can induce dormancy in prostate cancer cells by activating p38 signaling ${ }^{24}$. Mechanistically, binding of BMP7 to its receptor BMP receptor 2 (BMPR2) on prostate cancer cells activates p38 signaling; in turn, it induces reversible growth arrest by increasing the expression of the cell cycle inhibitor p21 and the metastasis suppressor gene NDRG1 (N-myc downstream-regulated gene 1). These data together show that many of these dormancy-inducing cytokines from the stroma can promote the $\mathrm{p} 38^{\text {high }} / \mathrm{ERK}^{\text {low }}$ state in the absence of proliferative signaling, resulting in G0 cell cycle arrest and cancer dormancy.

\section{Breaking of cellular dormancy by microenvironmental cues}

Integrins are transmembranous heterodimeric glycoproteins that mediate cell-to-cell and cell-to-ECM signaling cascades. Integrin signaling activates multiple intermediaries, including cytosolic tyrosine kinases, and is involved in the regulation of cell proliferation, survival, and motility in both cancer and normal healthy cells ${ }^{25}$. Numerous studies have provided evidence that integrin signaling, particularly $\beta-1$ integrin, is a critical regulator in the switch from cellular dormancy to metastatic growth in vitro and in vivo ${ }^{25-29}$. Loss of $\beta-1$ integrin signaling by downregulation of the uPA-uPAR interaction appears to promote the shift from a proliferative to a dormant state in cancer cells ${ }^{8}$. The inhibition of $\beta-1$ integrin signaling by antibody treatment induced the growth arrest of mammary cancer cells in a three-dimensional basement membrane assay $^{30}$. The removal of the anti- $\beta-1$ integrin antibody reversed cell cycle arrest and reinitiated cancer cell growth. Focal adhesion kinase (FAK) is a downstream molecule of $\beta-1$ integrin and has been implicated in the regulation of cancer cell dormancy. In a mouse mammary tumor virus (MMTV) transgenic breast cancer mouse model, the CreLoxP-mediated deletion of $\beta$-integrin results in a decrease in FAK phosphorylation, reduced cell proliferation, and growth arrest of tumor burden in vivo ${ }^{31}$. Similarly, the growth ability of a highly metastatic D2A1 mammary carcinoma cell was significantly dependent on the presence of fibronectin, $\beta-1$ integrin signaling, and downstream phosphorylation of the myosin complex in three-dimensional cell culture, suggesting that the upregulation of $\beta-1$ signaling enabled DCCs to re-enter the cell cycle ${ }^{26}$.

An additional in vivo study revealed that metastatic outgrowth of the mouse mammary cancer cell lines D2.0R and D2A1 was dependent on $\beta 1$-integrin signaling ${ }^{32}$. Binding of collagen to integrin receptors resulted in FAK/ SRC activation and subsequent ERK phosphorylation. Integrin-mediated ERK activation induced cell proliferation, driving metastatic outgrowth. These data suggest that the interaction between $\beta 1$-integrin/FAK and the MAPK pathway is essential for cancer cell growth. Meanwhile, noncanonical discoidin domain receptor 1 (DDR) signaling is also activated by binding to collagen, and it is known to activate cancer cell proliferation at metastatic $\operatorname{sites}^{33}$. Mechanistically, tetraspanin transmembrane 4 L six family member 1 (TM4SF1) couples DDR1 to syntenin 2 and then activates protein kinase $C$ alpha (PKC $\alpha)$. Activated PKC $\alpha$ subsequently phosphorylates Janus kinase 2 (JAK2) to drive noncanonical DDR1 signaling through phosphorylation of signal transducer and activator of transcription 3 (STAT3). In cancer, constitutive activation of STAT3 increases the transcription of cell cycle regulators, such as c-Myc and cyclin D, and promotes cancer cell proliferation. Consistently, histopathologic analysis of metastatic murine breast cancer cells has identified that micrometastatic tissues are surrounded by collagen. In metastatic tissues, the majority of cancer cells apart from collagen are dormant, whereas those nearby collagen are proliferative. These findings indicate how the interaction between DCCs and the ECM microenvironment influences cancer cell behavior and metastatic reactivation.

Furthermore, Wnt signaling has been implicated as a mediator during ECM-induced DCC reactivation. Wnt signaling is known to control diverse biological processes and is a well-known proliferation inducer. Wnt activation 
promotes G1-to-S progression through both transcriptional and nontranscriptional regulation of cyclin D1, cyclin E1, and $\mathrm{c}-\mathrm{myc}^{34}$. Therefore, inhibition of Wnt signaling by secretion of Dickkopf WNT signaling pathway inhibitor 1 (DKK1) is one mechanism by which cancer cells enter quiescence ${ }^{35}$. Tenascin C, initially produced by metastasis-initiating cancer cells and later secreted from stromal fibroblasts, is known to support the metastatic outgrowth of breast cancer cells by promoting Wnt signaling. Tenascin $C$ binds to syndecan-4, a coreceptor of the Wnt receptor Frizzled-7, thereby enhancing Wnt signaling activation and facilitating metastatic colonization. Additionally, periostin has the ability to recruit Wnt ligands; thus, it can increase the presentation of Wnt ligands to cancer cells. Periostin is mainly produced from stromal fibroblasts upon TGF- $\beta$ activation and can be secreted from endothelial tip cells that reside in new vascular sprouts. Thus, periostin is abundant in micrometastatic lesions undergoing neoangiogenesis and is a profound factor for a permissive microenvironment of cancer metastasis. Moreover, both tenascin $\mathrm{C}$ and periostin can foster integrin signaling through an indirect pathway; they coassemble with fibronectin and modulate its adhesiveness and stiffness, which collectively increase the integrin signaling capacity.

Collectively, these facts suggest that the ECM components from metastasis-initiating cancer cells and stromal cells may sculpt a permissive niche, facilitating the activation of signaling pathways that support metastatic cell proliferation.

\section{Chronic inflammation awakens dormant cells}

Growing evidence has suggested that chronic inflammation is involved in cancer development. For example, patients with inflammatory bowel disease are at higher risk of colorectal cancer development. Hepatitis and fatty liver disease correlate with the incidence of liver cancer development. Acid reflux esophagitis can cause esophageal cancer. Chronic Helicobacter infection is the leading cause of stomach cancer. During inflammation, free radicals such as reactive oxygen and nitrogen species (RONS) increase and induce double-strand breaks in DNA, which are potently mutagenic if not accurately and promptly repaired, thereby facilitating the transformation of normal healthy cells to cancer cells ${ }^{36}$. Moreover, free radicals can trigger a wide range of signaling pathways, including MAPK/ERK, PI3K/Akt, and IкB kinase/nuclear factor kappa-light-chain-enhancer of activated B cells $(\mathrm{NF} \kappa \mathrm{B})$, that lead to cancer malignancy ${ }^{37}$. However, not all individuals who have experienced chronic inflammatory diseases eventually develop cancer in their lifetime. In situ carcinoma can be found in the lesion without any chronic inflammation. These phenomena raised the question about whether a cause-effect relationship exists between chronic inflammation and cancer. One of the possible explanations for this conflicting evidence may be that reawakening DCCs could be a key factor for cancer development from chronic inflammation. For instance, chronic inflammation supports angiogenesis, which breaks cancer dormancy by supplying sufficient oxygen and nutrients and facilitates cancer growth ${ }^{38}$. Moreover, there is a strong correlation between inflammation and recurrence of cancer, including recurrence of endometrial $^{39}$, oral ${ }^{40}$, and breast cancer ${ }^{41,42}$. The escape of cancer from dormancy can be induced by the inflammatory cytokine interferon-gamma (IFN- $\gamma)^{43-46}$. In addition, the correlation between the high levels of serum inflammatory cytokines and cancer recurrence supports this hypothesis. In a cohort consisting of 734 breast cancer patients, high levels of circulating acute-phase proteins (APPs) were positively correlated with distant recurrence $^{47}$. Additionally, C-reactive protein (CRP) and interleukin 6 (IL-6), other serum inflammatory markers, have shown their possibilities as posttreatment prognostic monitoring factors for predicting the risk of cancer recurrence and patient death ${ }^{48-50}$. Hepatocyte CRP secretion is controlled by interleukin 6 (IL-6). The synthesis of CRP is stimulated by interleukin-1 (IL-1) and tumor necrosis factor (TNF). A rise in serum levels of CRP often reflects tissue damage. Collectively, these data support the hypothesis that inflammation can be the DCC reawakening factor and therefore can function as a cancer-promoting factor.

Chronic inflammation can induce epigenetic alterations and DNA mutations in tumor suppressor genes, thereby facilitating carcinogenesis. Fortunately, the immune system can recognize these mutant protein antigens of cancer cells and can attack cancer cells, serving as a critical mechanism of metastatic dormancy, so-called immunogenic cancer dormancy ${ }^{51,52}$. For instance, CD8 $+\mathrm{T}$ cells have a cytostatic effect on cancer cells, thereby allowing early disseminated cancer cells to stay in a dormant state at metastatic sites ${ }^{53}$. In some experimental models, removal of CD8 $+\mathrm{T}$ cells resulted in outgrowth of DCCs and induced cancer recurrence ${ }^{53}$. However, chronic inflammation can also facilitate other mechanisms that promote the reactivation of DCCs. For instance, studies in a pancreatic cancer mouse model demonstrated that circulating cancer cells underwent epithelial to mesenchymal transition (EMT) and seeded metastatic colonies in the liver. In this process, the rate of EMT and invasive potential were highest at the sites of inflammation. On the other hand, treatment with dexamethasone, an immunosuppressive drug, abrogated EMT and cancer invasiveness. These results imply that inflammation can be a cancer progression factor by facilitating the EMT process in cancer cells ${ }^{54}$. Similarly, localized inflammation in the lungs can trigger cancer cell escape from dormancy, 
which leads to the development of macroscopic metas$\operatorname{tases}^{30}$. During this process, Zeb1 expression, a strong inducer of EMT, was required for cancer cells to escape dormancy. On the other hand, depletion of neutrophils via the administration of antibodies against the lymphocyte antigen 6 complex, locus G (Ly6G) abrogated the reactivation of DCCs.

The interaction between cancer cells and myeloid cells has also been implicated in cancer progression. For instance, inflammatory monocytes with Ly6C expression can facilitate the extravasation of cancer cells in the lung by secreting chemokine C-C-motif ligand $2(\mathrm{CCL} 2)^{55}$ and vascular endothelial growth factor ${ }^{56}$. Then, macrophages bind to cancer cells and increase the survival of cancer cells. In this procedure, vascular cell adhesion protein 1 on cancer cells binds to $\beta$-1-integrin-positive macrophages, and this interaction activates Akt signaling in cancer cells and allows them to evade TNF-related apoptosis-inducing ligand (TRAIL)-induced apoptosis ${ }^{57}$. Together, these mechanistic roles of myeloid cells are related to metastasis-promoting effects. However, whether the interaction between myeloid cells and cancer cells switches on the growth of DCCs has not yet been sufficiently demonstrated.

The differentiation of monocytes into metastasisassociated macrophages (MAMs) can promote the metastatic outgrowth of cancer cells. The metastasispromoting role of MAMs is more complicated and related to their participation in sculpting a more fibrotic metastatic microenvironment. In a genetic mouse model of pancreatic ductal adenocarcinoma (PDAC), MAMs secreted granulin in the liver, and granulin induced the transformation of resident hepatic stellate cells into myofibroblasts. In turn, myofibroblasts secreted periostin, which created a fibrotic microenvironment that was more favorable for integrin singling activation ${ }^{58}$. Then, activated integrin signaling led to DCC reactivation and promoted the proliferation of cancer cells at the metastatic lesion. Therefore, the development of a more fibrotic metastatic microenvironment by MAMs can function as a prometastatic factor by awakening DCCs.

The involvement of natural killer (NK) cells in cancer dormancy and reactivation has not yet been determined, and instead, it has been elucidated that DCCs are more resistant to the cytotoxicity of NK cells. In a "latencycompetent cancer model" where dormant clones were selected from an in vivo experimental metastasis assay, DCCs were confirmed to activate the p38 and self-renewal pathways through Sox2/9. Sox2 was also shown to facilitate DKK1 secretion and thereby inhibit Wnt signaling as well as downstream proliferative pathways ${ }^{35}$. Once DCCs enter dormancy via DKK1, they are able to avoid NK cellmediated cell death, while DCCs with low DKK1 expression are still proliferative and susceptible to NK cell cytotoxicity.
Recently, a growing body of evidence has highlighted the potential role of $\mathrm{CD} 4$ and $\mathrm{CD} 8 \mathrm{~T}$ cells in cancer dormancy maintenance ${ }^{59,60}$. DCCs were far less susceptible to adaptive immunity and showed low expression of cancer antigen. Additionally, dormant leukemia cells were confirmed to express PDL-1, which allows them to avoid $\mathrm{T}$ cell-mediated cytotoxicity ${ }^{59,60}$. These findings indicate that DCCs can escape anticancer immunity, thereby surviving for an extended period. Additionally, an in vivo xenograft model using dormant murine breast cancer cell clones selected with constitutive treatment of doxorubicin has revealed that both CD8 and CD4 T cells are involved in chemotherapy-mediated dormancy as well ${ }^{61}$. Chemotherapy treatment activated IFN signaling in cancer cells through an autocrine and self-sustained increase in TF and interferon regulatory factor 7 (IRF7). IRF7/IFN signaling promoted the expansion of $\mathrm{CD} 4$ and $\mathrm{CD} 8$ $\mathrm{T}$ cells and prevented the mobilization of $\mathrm{CD} 11 \mathrm{~b}^{+} \mathrm{Gr} 1^{+}$ myeloid-derived suppressor cells. Collectively, these effects facilitate immune cytotoxicity, resulting in immune-mediated cancer dormancy.

More recently, neutrophils have attracted significant attention because of their DCC-reawakening activity. Exposure to tobacco smoke or the nasal instillation of lipopolysaccharide induced chronic lung inflammation and converted DCCs to aggressively growing cancer cells, resulting in an increase in metastasis. In this process, neutrophils mediated the DCC reawakening through the formation of neutrophil extracellular traps (NETs), which are scaffolds of chromatin, including cytotoxic enzymes and proteases that are released into the extracellular space $^{62}$. Mechanistically, two proteases, neutrophil elastase and matrix metalloproteinase 9 (MMP9), were secreted from NETs and sequentially cleaved and remodeled laminin. In turn, the remodeled laminin activated integrin $\alpha 3 \beta 1$ signaling in DCCs and promoted their proliferation. Treatment with antibodies against NETremodeled laminin prevented the awakening of DCCs and reduced metastasis.

\section{Summary and direction of future research}

In inhospitable microenvironments, cancer cells may enter a state of dormancy to protect themselves against apoptotic and antiproliferative treatments so that the fittest may survive ${ }^{63,64}$. The existence of DCCs has led to the emergence of therapy resistance, and most importantly, the cells may resume growth, raising the risk of lethal metastatic outbreaks even after a long latency period of months to years. For these reasons, DCCs have been attracting significant interest as a therapeutic target for improving clinical outcomes. The removal of DCCs in combination with antiproliferative treatment is one therapeutic option; however, cellular and surface markers for DCCs are mostly unavailable at present. An overwhelming number of reports 
propose that DCC reawakening is the final step of the metastatic outbreak, so blocking the factors responsible for this process is key to preventing poor clinical outcomes. Although a variety of signaling cascades are linked to the breaking of dormancy, these signaling networks eventually lead to a change in the balance between p38 and ERK activities in favor of $\mathrm{ERK}^{8}$. Therefore, if we can finely modulate the balance of p38 and ERK, we may be able to induce permanent dormancy and prevent metastasis, which will mark a new era of cancer treatment.

In the present review, we provide an overview of the cellular and acellular mechanisms that break the dormancy-permissive $\mathrm{p} 38^{\text {high }} /$ ERK $^{\text {low }}$ status (Fig. 1). During their journey in the blood and lymphatic stream, DCCs do not interact with local cells or the ECM. However, once they reach an organ, they encounter a new combination of ECM, growth factors, and cytokines produced from local stromal and immune cells. The binding of fibronectin to integrins has a fundamental role in shifting the balance of p38 and ERK activities in favor of ERK. Additionally, other ECM components, such as tenascin $\mathrm{C}$ and periostin secreted from resident stromal cells, can foster the binding of fibronectin and integrins and can therefore act as substantial DCC-reawakening factors. In addition, chronic inflammation can initiate the regrowth of DCCs through integrin activation. Macrophages promote the secretion of fibronectin from nearby fibroblasts and sculpt a more fibrotic metastatic microenvironment, thereby fostering the binding of fibronectin to integrin on DCCs. Additionally, neutrophils participate in ECM remodeling by secreting proteinase enzymes, sequentially activating integrin signaling, and reawakening DCCs. Other immune cells, such as monocytes and myeloid cells, have functional involvement in triggering escape from dormancy in multiple experimental models, although their necessity in integrin signaling activation has not yet been tested. Several target molecules that are involved in DCC reawakening are currently under clinical

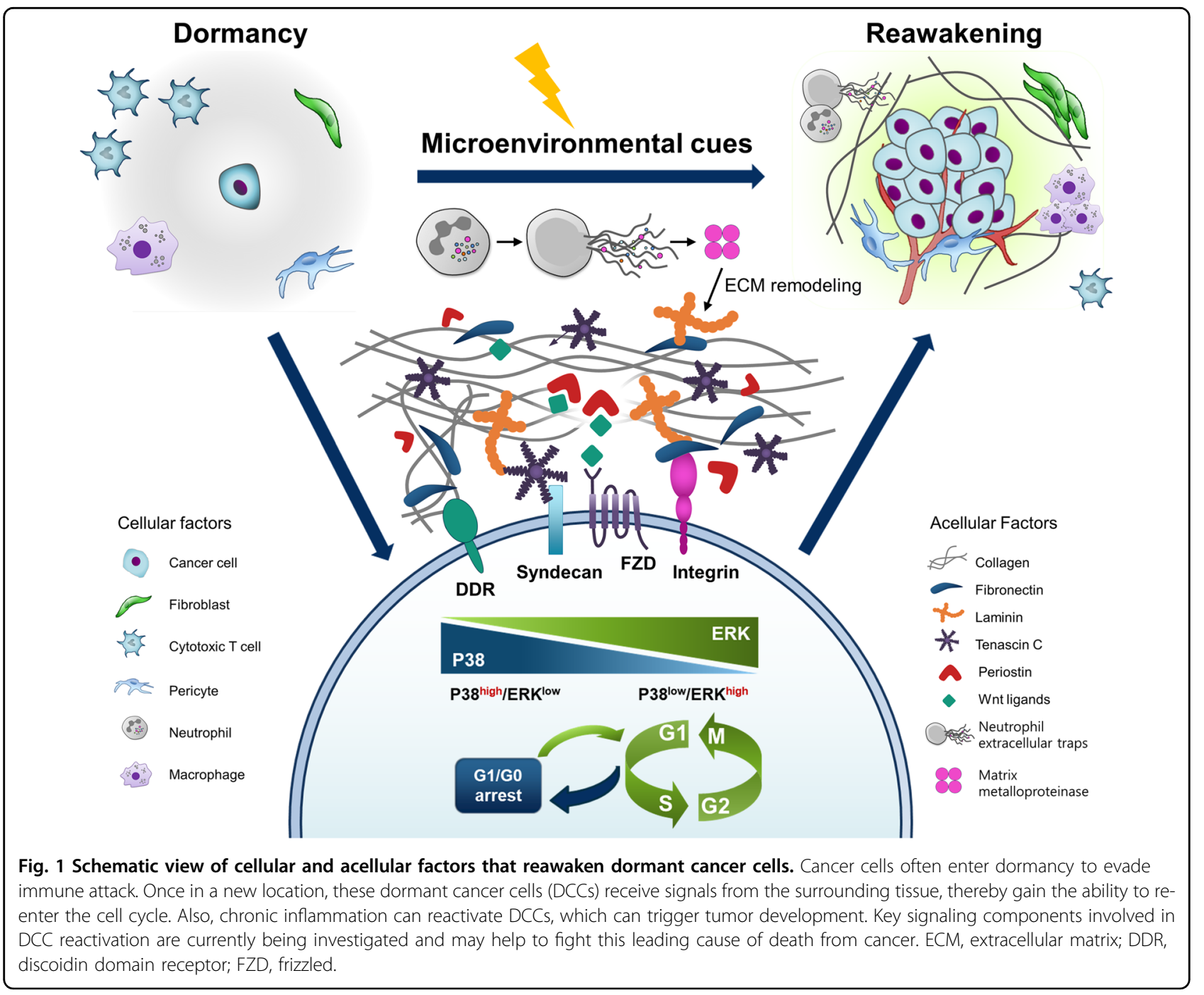


Table 1 Potential molecular targets and therapeutic agents linked to the DCC reawakening mechanism.

\begin{tabular}{|c|c|c|c|c|c|c|c|}
\hline Target & Drug & Strategy & Clinical trial & Treatment & Current status & Disease & Clinical results \\
\hline \multirow[t]{2}{*}{$\begin{array}{l}\text { Integrin } \\
\beta 1\end{array}$} & ATN-161 & $\begin{array}{l}\text { Non-RGD-based } \\
\text { integrin-binding } \\
\text { peptide }\end{array}$ & $\begin{array}{l}\text { Phase I/II } \\
\text { (NCT00352313) }\end{array}$ & $\begin{array}{l}\text { Combinatory } \\
\text { (with carboplatin) }\end{array}$ & Completed & $\begin{array}{l}\text { Recurrent malignant } \\
\text { glioma }\end{array}$ & $\begin{array}{l}\text { All of the treatment-related } \\
\text { adverse } \\
\text { events were grade } 2 \text { or } \\
\text { lower }^{65} \text {. }\end{array}$ \\
\hline & & & $\begin{array}{l}\text { Phase II } \\
\text { (NCT00131651) }\end{array}$ & Single & Terminated & $\begin{array}{l}\text { Advanced renal cell } \\
\text { carcinoma }\end{array}$ & Unposted \\
\hline \multirow[t]{7}{*}{$\begin{array}{l}\text { Integrin } \\
\text { a5 } \beta 1\end{array}$} & Volociximab & $\begin{array}{l}\text { Chimeric monoclonal } \\
\text { antibody against } \\
\text { integrin a5 } \beta 1\end{array}$ & $\begin{array}{l}\text { Phase lb } \\
\text { (NCT00666692, } \\
\text { NCT00654758) }\end{array}$ & $\begin{array}{l}\text { Combinatory (with } \\
\text { carboplatin, } \\
\text { paclitaxel, } \\
\text { bevacizumab) }\end{array}$ & Completed & $\begin{array}{l}\text { Advanced non-small-cell lung } \\
\text { cancer (NSCLC) }\end{array}$ & $\begin{array}{l}\text { Treatment was well tolerated, } \\
\text { and dose-limiting toxicities } \\
\text { were not observed. } \\
\text { Approximately one } \\
\text {-quarter of patients displayed } \\
\text { stable disease }{ }^{66} \text {. }\end{array}$ \\
\hline & & & $\begin{array}{l}\text { Phase II } \\
\text { (NCT00369395) }\end{array}$ & Single & Terminated & Metastatic melanoma & $\begin{array}{l}\text { Terminated because of } \\
\text { insufficient } \\
\text { clinical activity }\end{array}$ \\
\hline & & & $\begin{array}{l}\text { Phase II } \\
\text { (NCT00099970) }\end{array}$ & $\begin{array}{l}\text { Combinatory (with } \\
\text { dacarbazine) }\end{array}$ & Completed & Metastatic melanoma & Unposted \\
\hline & & & $\begin{array}{l}\text { Phase II } \\
\text { (NCT00516841) }\end{array}$ & Single & Terminated & $\begin{array}{l}\text { Platinum-resistant advanced } \\
\text { epithelial ovarian cancer, } \\
\text { primary peritoneal cancer }\end{array}$ & $\begin{array}{l}\text { Terminated based on lack of } \\
\text { efficacy }\end{array}$ \\
\hline & & & $\begin{array}{l}\text { Phase II } \\
\text { (NCT00401570) }\end{array}$ & $\begin{array}{l}\text { Combinatory (with } \\
\text { gemcitabine) }\end{array}$ & Completed & Metastatic pancreatic cancer & Unposted \\
\hline & & & $\begin{array}{l}\text { Phase II } \\
\text { (NCT00100685) }\end{array}$ & Single & Terminated & $\begin{array}{l}\text { Metastatic renal cell } \\
\text { carcinoma }\end{array}$ & Unposted \\
\hline & & & $\begin{array}{l}\text { Phase I/II } \\
\text { (NCT00635193) }\end{array}$ & $\begin{array}{l}\text { Combinatory (with } \\
\text { doxorubicin) }\end{array}$ & Completed & $\begin{array}{l}\text { Ovarian cancer, primary } \\
\text { peritoneal cancer }\end{array}$ & Unposted \\
\hline \multirow[t]{5}{*}{$\begin{array}{l}\text { Integrin } \\
\text { a2 }\end{array}$} & E7820 & $\begin{array}{l}\text { Oral inhibitor of } \\
\text { integrin alpha-2 } \\
\text { expression } \\
\text { (sulfonamide-based } \\
\text { small molecule) }\end{array}$ & $\begin{array}{l}\text { Phase I } \\
\text { (NCT01773421) }\end{array}$ & Single & Completed & Advanced solid tumors & $\begin{array}{l}\text { E7820 decreases integrin } \\
\text { alpha- } 2 \text { in surrogate tissues } \\
\text { and is associated with stable } \\
\text { disease }^{68} \text {. }\end{array}$ \\
\hline & & & $\begin{array}{l}\text { Phase I/II } \\
\text { (NCT01347645) }\end{array}$ & Single & Completed & $\begin{array}{l}\text { Locally advanced/metastatic } \\
\text { colon/rectal cancer }\end{array}$ & $\begin{array}{l}\text { E7820 treatment was safe and } \\
\text { tolerable in } 2 / 3 \text { of patients }{ }^{69} \text {. }\end{array}$ \\
\hline & & & $\begin{array}{l}\text { Phase I/II } \\
\text { (NCT01133990) }\end{array}$ & $\begin{array}{l}\text { Combinatory (with } \\
\text { FOLIRI) }\end{array}$ & Completed & $\begin{array}{l}\text { Locally advanced/metastatic } \\
\text { colon/rectal cancer }\end{array}$ & $\begin{array}{l}\text { Limited efficacy in locally } \\
\text { advanced or metastatic } \\
\text { colorectal carcinoma }^{69} \text {. }\end{array}$ \\
\hline & & & $\begin{array}{l}\text { Phase II } \\
\text { (NCT00309179) }\end{array}$ & $\begin{array}{l}\text { Combinatory (with } \\
\text { cetuximab) }\end{array}$ & Completed & Advanced colorectal cancer & $\begin{array}{l}\text { E7820 combined with } \\
\text { cetuximab is well tolerated. A } \\
\text { single partial response was } \\
\text { observed in a total of seven } \\
\text { KRAS-mutant pateints }{ }^{70} \text {. }\end{array}$ \\
\hline & & & $\begin{array}{l}\text { Phase I } \\
\text { (NCT00078637) }\end{array}$ & Single & Completed & $\begin{array}{l}\text { Neoplasms, lymphoma, } \\
\text { malignant cancers }\end{array}$ & Unposted \\
\hline \multirow[t]{3}{*}{$\begin{array}{l}\text { Integrin } \\
\text { av }\end{array}$} & $\begin{array}{l}\text { Intetumumab } \\
\text { (CNTO-95) }\end{array}$ & $\begin{array}{l}\text { Panintegrin av } \\
\text { antibody }\end{array}$ & $\begin{array}{l}\text { Phase I } \\
\text { (NCT00888043) }\end{array}$ & $\begin{array}{l}\text { Combinatory (with } \\
\text { Avastin) }\end{array}$ & Completed & Solid tumors & Unposted \\
\hline & & & $\begin{array}{l}\text { Phase II } \\
\text { (NCT00537381) }\end{array}$ & $\begin{array}{l}\text { Combinatory (with } \\
\text { docetaxel and } \\
\text { prednisone) }\end{array}$ & Completed & $\begin{array}{l}\text { Metastatic hormone- } \\
\text { refractory prostate cancer }\end{array}$ & $\begin{array}{l}\text { Treatment resulted in shorter } \\
\text { progression-free survival } \\
\text { without additional toxicity }{ }^{71} \text {. }\end{array}$ \\
\hline & & & $\begin{array}{l}\text { Phase I/II } \\
\text { (NCT00246012) }\end{array}$ & $\begin{array}{l}\text { Single or } \\
\text { combinatory (with } \\
\text { dacarbazine) }\end{array}$ & Completed & Melanoma (stage 4) & $\begin{array}{l}\text { CNTO-95 showed a favorable } \\
\text { safety profile and } \\
\text { nonsignificant effects on } \\
\text { overall survival }^{22} \text {. }\end{array}$ \\
\hline \multirow[t]{3}{*}{$\begin{array}{l}\text { Integrin } \\
\text { av }\end{array}$} & Abituzumab & $\begin{array}{l}\text { Panintegrin av } \\
\text { antibody }\end{array}$ & $\begin{array}{l}\text { Phase I } \\
\text { (NCT00848510) }\end{array}$ & Single & Completed & $\begin{array}{l}\text { Colorectal/ovarian cancer } \\
\text { with liver metastases }\end{array}$ & $\begin{array}{l}\text { It was tolerable despite } \\
\text { hypersensitivity reactions }{ }^{73} \text {. }\end{array}$ \\
\hline & & & $\begin{array}{l}\text { Phase I/II } \\
\text { (NCT01008475) }\end{array}$ & $\begin{array}{l}\text { Combinatory (with } \\
\text { irinotecan and } \\
\text { cetuximab) }\end{array}$ & Completed & $\begin{array}{l}\text { Kras-wild-type metastatic } \\
\text { colorectal cancer }\end{array}$ & $\begin{array}{l}\text { A trend toward improved } \\
\text { overall survival was } \\
\text { observed }^{74} \text {. }\end{array}$ \\
\hline & & & $\begin{array}{l}\text { Phase II } \\
\text { (NCT01360840) }\end{array}$ & Single & Completed & $\begin{array}{l}\text { Asymptomatic/mildly } \\
\text { symptomatic metastatic } \\
\text { castrate-resistant } \\
\text { prostate cancer }\end{array}$ & $\begin{array}{l}\text { Although progression-free } \\
\text { survival was not significantly } \\
\text { extended, abituzumab } \\
\text { appears to have specific } \\
\text { activity in prostate cancer- } \\
\text { associated bone lesions }{ }^{75} \text {. }\end{array}$ \\
\hline \multirow[t]{3}{*}{$\begin{array}{l}\text { Integrin } \\
\text { avß3 }\end{array}$} & $\begin{array}{l}\text { Etaratuzumab } \\
\text { (MEDI-522) }\end{array}$ & $\begin{array}{l}\text { Humanized higher- } \\
\text { affinity variants } \\
\text { derived from murine } \\
\text { antibody LM609 }\end{array}$ & $\begin{array}{l}\text { Phase I/II } \\
\text { (NCT00027729) }\end{array}$ & Single & Completed & Advanced colorectal cancer & Unposted \\
\hline & & & $\begin{array}{l}\text { Phase I } \\
\text { (NCT00049712) }\end{array}$ & Single & Completed & $\begin{array}{l}\text { Refractory advanced solid } \\
\text { tumors, lymphoma }\end{array}$ & Unposted \\
\hline & & & $\begin{array}{l}\text { Phase I/II } \\
\text { (NCT00284817) }\end{array}$ & Single & Completed & $\begin{array}{l}\text { Irinotecan-refractory } \\
\text { advanced colorectal cancer }\end{array}$ & Unposted \\
\hline
\end{tabular}


Table 1 continued

\begin{tabular}{|c|c|c|c|c|c|c|c|}
\hline Target & Drug & Strategy & Clinical trial & Treatment & Current status & Disease & Clinical results \\
\hline & & & $\begin{array}{l}\text { Phase II } \\
\text { (NCT00072930) }\end{array}$ & $\begin{array}{l}\text { Combinatory (with } \\
\text { docetaxel, } \\
\text { prednisone, } \\
\text { zoledronic acid) }\end{array}$ & Completed & $\begin{array}{l}\text { Metastatic androgen- } \\
\text { independent prostate cancer }\end{array}$ & Unposted \\
\hline & & & $\begin{array}{l}\text { Phase 1/II } \\
\text { (NCT00684996) }\end{array}$ & $\begin{array}{l}\text { Combinatory (with } \\
\text { bevacizumab) }\end{array}$ & Terminated & $\begin{array}{l}\text { Unresectable/metastatic } \\
\text { kidney cancer }\end{array}$ & Posted \\
\hline & & & $\begin{array}{l}\text { Phase I } \\
\text { (NCT00263783) }\end{array}$ & Single & Completed & Refractory solid tumors & Unposted \\
\hline & & & $\begin{array}{l}\text { Phase II } \\
\text { (NCT00066196) }\end{array}$ & $\begin{array}{l}\text { Single or } \\
\text { combinatory (with } \\
\text { dacarbazine) }\end{array}$ & Completed & Metastatic melanoma & $\begin{array}{l}\text { MEDI- } 522 \text { appears to be well } \\
\text { tolerated. The overall survival } \\
\text { results suggested potential } \\
\text { clinical activity of MEDI- } 522^{76} \text {. }\end{array}$ \\
\hline & & & $\begin{array}{l}\text { Phase I } \\
\text { (NCT00111696) }\end{array}$ & Single & Completed & $\begin{array}{l}\text { Advanced malignant } \\
\text { melanoma }\end{array}$ & Unposted \\
\hline $\begin{array}{l}\text { Integrin } \\
\text { av }\end{array}$ & MK-0429 & $\begin{array}{l}\text { An equipotent } \\
\text { inhibitor of multiple } \\
\text { av integrins }\end{array}$ & $\begin{array}{l}\text { Phase I } \\
\text { (NCT00302471) }\end{array}$ & Single & Completed & $\begin{array}{l}\text { Prostate cancer with } \\
\text { metastatic bone disease }\end{array}$ & $\begin{array}{l}\text { MK-0429 was generally well } \\
\text { tolerated and a reduction in } \\
\text { bone turnover was } \\
\text { observed }^{77} \text {. }\end{array}$ \\
\hline \multirow{11}{*}{$\begin{array}{l}\text { Integrin } \\
\text { av } \beta 3 \\
\text { and } \\
\text { av } \beta 5\end{array}$} & $\begin{array}{l}\text { Cilengitide } \\
\text { (EMD121974) }\end{array}$ & $\begin{array}{l}\text { A constrained cyclic } \\
\text { pentapeptide based } \\
\text { on the RGD sequence }\end{array}$ & $\begin{array}{l}\text { Phase II } \\
\text { (NCT00103337) }\end{array}$ & Single & Completed & Metastatic prostate cancer & Unposted \\
\hline & & & $\begin{array}{l}\text { Phase II } \\
\text { (NCT00089388) }\end{array}$ & Single & $\begin{array}{l}\text { Terminated } \\
\text { (administratively } \\
\text { complete) }\end{array}$ & Acute myeloid leukemia & Unposted \\
\hline & & & $\begin{array}{l}\text { Phase I } \\
\text { (NCT00063973) }\end{array}$ & Single & Completed & $\begin{array}{l}\text { Children with refractory } \\
\text { primary brain tumors }\end{array}$ & Unposted \\
\hline & & & $\begin{array}{l}\text { Phase I } \\
\text { (NCT01118676) }\end{array}$ & $\begin{array}{l}\text { Combinatory (with } \\
\text { radiochemotherapy) }\end{array}$ & Completed & Locally advanced NSCLC & Unposted \\
\hline & & & $\begin{array}{l}\text { Phase II } \\
\text { (NCT00679354) }\end{array}$ & Single & Completed & $\begin{array}{l}\text { Recurrent/Progressive high- } \\
\text { grade glioma that has not } \\
\text { responded to a standard } \\
\text { regimen }\end{array}$ & Posted \\
\hline & & & $\begin{array}{l}\text { Phase I } \\
\text { (NCT00022113) }\end{array}$ & Single & Completed & Advanced solid tumors & $\begin{array}{l}\text { Dose-limiting toxicity was not } \\
\text { observed }^{78} \text {. }\end{array}$ \\
\hline & & & $\begin{array}{l}\text { Phase II } \\
\text { (NCT00121238) }\end{array}$ & Single & Completed & Prostate cancer & $\begin{array}{l}\text { Cilengitide was well tolerated } \\
\text { but had no detectable clinical } \\
\text { activity }{ }^{78} \text {. }\end{array}$ \\
\hline & & & $\begin{array}{l}\text { Phase II } \\
\text { (NCT00093964) }\end{array}$ & Single & Completed & $\begin{array}{l}\text { Recurrent glioblastoma } \\
\text { multiforme }\end{array}$ & Posted \\
\hline & & & $\begin{array}{l}\text { Phase II } \\
\text { (NCT01517776) }\end{array}$ & $\begin{array}{l}\text { Combinatory (with } \\
\text { temozolomide) }\end{array}$ & $\begin{array}{l}\text { Terminated (due } \\
\text { to an altered } \\
\text { benefit/risk ratio) }\end{array}$ & $\begin{array}{l}\text { Refractory high-grade } \\
\text { gliomas, diffuse intrinsic } \\
\text { pontine gliomas in children } \\
\text { and adolescents }\end{array}$ & Unposted \\
\hline & & & $\begin{array}{l}\text { Phase I } \\
\text { (NCT00077155) }\end{array}$ & Single & Completed & $\begin{array}{l}\text { Advanced solid tumors, } \\
\text { lymphoma }\end{array}$ & Unposted \\
\hline & & & $\begin{array}{l}\text { Phase I/II } \\
\text { (NCT00006093) }\end{array}$ & Single & Completed & Progressive/recurrent glioma & $\begin{array}{l}\text { No dose-limiting toxicity was } \\
\text { observed }^{8} \text {. }\end{array}$ \\
\hline \multirow[t]{3}{*}{ UPA } & $W X-671$ & $\begin{array}{l}\text { Orally available } \\
\text { prodrug of WX-UK1 }\end{array}$ & $\begin{array}{l}\text { Phase II } \\
\text { (NCT00499265) }\end{array}$ & $\begin{array}{l}\text { Combinatory (with } \\
\text { gemcitabine) }\end{array}$ & Completed & $\begin{array}{l}\text { Locally advanced pancreatic } \\
\text { cancer that cannot be } \\
\text { removed by surgery }\end{array}$ & $\begin{array}{l}\text { More patients achieved a } \\
\text { partial response with WX- } 671 \\
\text { combination therapy than } \\
\text { with standard of care }{ }^{79} \text {. }\end{array}$ \\
\hline & & & $\begin{array}{l}\text { Phase II } \\
\text { (NCT00615940) }\end{array}$ & $\begin{array}{l}\text { Combinatory (with } \\
\text { Capecitabine) }\end{array}$ & Completed & $\begin{array}{l}\text { Her2-negative metastatic } \\
\text { breast cancer }\end{array}$ & Unposted \\
\hline & WX-UK1 & $\begin{array}{l}\text { A serine protease } \\
\text { inhibitor that inhibits } \\
\text { UPA as well as other } \\
\text { serine proteases }\end{array}$ & $\begin{array}{l}\text { Phase I } \\
\text { (NCT00083525) }\end{array}$ & $\begin{array}{l}\text { Combinatory (with } \\
\text { capecitabine) }\end{array}$ & Completed & Advanced malignancies & Unposted \\
\hline \multirow[t]{3}{*}{ FAK } & GSK2256098 & $\begin{array}{l}\text { A tyrosine kinase } \\
\text { inhibitor working at } \\
\text { the } \\
\text { autophosphorylation } \\
\text { site (Tyr 397) of FAK }\end{array}$ & $\begin{array}{l}\text { Phase I } \\
\text { (NCT01938443) }\end{array}$ & $\begin{array}{l}\text { Combinatory (with } \\
\text { trametinib) }\end{array}$ & Completed & Advanced solid tumors & $\begin{array}{l}\text { Trametinib exposure was } \\
\text { increased in combination with } \\
\text { GSK2256098. Clinical efficacy } \\
\text { was limited in combinatory } \\
\text { therapy. The safety profile was } \\
\text { acceptable }^{80} \text {. }\end{array}$ \\
\hline & & & $\begin{array}{l}\text { Phase I } \\
\text { (NCT01138033) }\end{array}$ & Single & Completed & Solid tumors & $\begin{array}{l}\text { GSK2256098 has an } \\
\text { acceptable safety profile and } \\
\text { has clinical activity in patients } \\
\text { with mesothelioma, } \\
\text { particularly those with merlin } \\
\text { loss }^{81} \text {. }\end{array}$ \\
\hline & & & & Single & Completed & Healthy volunteers & Unposted \\
\hline
\end{tabular}


Table 1 continued

\begin{tabular}{|c|c|c|c|c|c|c|c|}
\hline Target & Drug & Strategy & Clinical trial & Treatment & Current status & Disease & Clinical results \\
\hline & & & $\begin{array}{l}\text { Phase I } \\
\text { (NCT00996671) } \\
\text { Phase II } \\
\text { (NCT02523014) }\end{array}$ & Single & $\begin{array}{l}\text { Suspended (not } \\
\text { currently open to } \\
\text { patient } \\
\text { registration) }\end{array}$ & $\begin{array}{l}\text { Intracranial meningioma, } \\
\text { recurrent meningioma with } \\
\text { NF2 gene mutation }\end{array}$ & Unposted \\
\hline & & & $\begin{array}{l}\text { Phase II } \\
\text { (NCT02428270) }\end{array}$ & $\begin{array}{l}\text { Combinatory (with } \\
\text { trametinib) }\end{array}$ & $\begin{array}{l}\text { Active, not } \\
\text { recruiting }\end{array}$ & Advanced pancreatic cancer & $\begin{array}{l}\text { The GSK2256098 and } \\
\text { trametinib combination was } \\
\text { well tolerated but was not } \\
\text { effective in patients }{ }^{82} \text {. }\end{array}$ \\
\hline & VS-4718 & $\begin{array}{l}\text { VS-4718 blocks } \\
\text { fibronectin-stimulated } \\
\text { FAK } \\
\text { autophosphorylation } \\
\text { at Tyr397 }\end{array}$ & $\begin{array}{l}\text { Phase I } \\
\text { (NCT02651727) }\end{array}$ & $\begin{array}{l}\text { Combinatory (with } \\
\text { paclitaxel and } \\
\text { gemcitabine) }\end{array}$ & Terminated & Pancreatic cancer & Unposted \\
\hline & & & $\begin{array}{l}\text { Phase I } \\
\text { (NCT01849744) }\end{array}$ & Single & $\begin{array}{l}\text { Terminated } \\
\text { (sponsor's } \\
\text { decision to } \\
\text { deprioritize the } \\
\text { program) }\end{array}$ & $\begin{array}{l}\text { Nonhematologic cancers, } \\
\text { metastatic cancer }\end{array}$ & Unposted \\
\hline & & & $\begin{array}{l}\text { Phase I } \\
\text { (NCT02215629) }\end{array}$ & Single & Withdrawn & $\begin{array}{l}\text { Acute myeloid leukemia, B } \\
\text { cell acute lymphoblastic } \\
\text { leukemia }\end{array}$ & - \\
\hline & $\begin{array}{l}\text { VS-6063 } \\
\text { (defatinib) }\end{array}$ & $\begin{array}{l}\text { VS- } 6063 \text { inhibits FAK } \\
\text { phosphorylation at } \\
\text { the Tyr397 }\end{array}$ & $\begin{array}{l}\text { Phase I } \\
\text { (NCT00787033) }\end{array}$ & Single & Completed & $\begin{array}{l}\text { Advanced nonhematologic } \\
\text { malignancies }\end{array}$ & $\begin{array}{l}\text { VS- } 6063 \text { has an acceptable } \\
\text { safety profile. Treatment- } \\
\text { related adverse events were } \\
\text { mild to moderate, and } \\
\text { reversible }{ }^{83} \text {. }\end{array}$ \\
\hline & & & $\begin{array}{l}\text { Phase I } \\
\text { (NCT01943292) }\end{array}$ & Single & Completed & Nonhematologic cancers & Posted \\
\hline & & & $\begin{array}{l}\text { Phase } 1 / 1 \mathrm{lb} \\
\text { (NCT01778803) }\end{array}$ & $\begin{array}{l}\text { Combinatory (with } \\
\text { paclitaxel) }\end{array}$ & Completed & Advanced ovarian cancer & $\begin{array}{l}\text { Defactinib was generally well } \\
\text { tolerated in combination with } \\
\text { weekly paclitaxel }^{84} \text {. }\end{array}$ \\
\hline & & & $\begin{array}{l}\text { Phase I } \\
\text { (NCT03875820) }\end{array}$ & $\begin{array}{l}\text { Combinatory (with } \\
\text { RO5126766) }\end{array}$ & Recruiting & $\begin{array}{l}\text { NSCLC, solid tumors, low- } \\
\text { grade serous ovarian cancer, } \\
\text { colorectal cancer }\end{array}$ & - \\
\hline & & & $\begin{array}{l}\text { Phase I } \\
\text { (NCT02546531) }\end{array}$ & $\begin{array}{l}\text { Combinatory (with } \\
\text { pembrolizumab and } \\
\text { gemcitabine) }\end{array}$ & $\begin{array}{l}\text { Active, not } \\
\text { recruiting }\end{array}$ & $\begin{array}{l}\text { Advanced solid tumors, solid } \\
\text { tumors, pancreatic cancer }\end{array}$ & - \\
\hline & & & $\begin{array}{l}\text { Phase I/II } \\
\text { (NCT02758587) }\end{array}$ & $\begin{array}{l}\text { Combinatory (with } \\
\text { pembrolizumab) }\end{array}$ & Recruiting & $\begin{array}{l}\text { Carcinoma, NSCLC, } \\
\text { mesothelioma, pancreatic } \\
\text { neoplasm }\end{array}$ & - \\
\hline & & & $\begin{array}{l}\text { Phase II } \\
\text { (NCT01951690) }\end{array}$ & Single & Completed & $\begin{array}{l}\text { Non-small-cell lung cancer, } \\
\text { lung cancer }\end{array}$ & $\begin{array}{l}\text { Defactinib monotherapy } \\
\text { showed modest clinical } \\
\text { activity in heavily pretreated } \\
\text { patients with KRAS } \\
\text { mutation }^{85} \text {. }\end{array}$ \\
\hline & & & $\begin{array}{l}\text { Phase II } \\
\text { (NCT02004028) }\end{array}$ & Single & $\begin{array}{l}\text { Terminated } \\
\text { (company } \\
\text { decided to } \\
\text { discontinue trial } \\
\text { to focus on } \\
\text { development } \\
\text { program } \\
\text { next steps) }\end{array}$ & $\begin{array}{l}\text { Surgically resectable } \\
\text { malignant pleural } \\
\text { mesothelioma }\end{array}$ & Unposted \\
\hline & & & $\begin{array}{l}\text { Phase II } \\
\text { (NCT03727880) }\end{array}$ & $\begin{array}{l}\text { Combinatory (with } \\
\text { pembrolizumab) }\end{array}$ & Recruiting & $\begin{array}{l}\text { Resectable pancreatic ductal } \\
\text { adenocarcinoma }\end{array}$ & - \\
\hline PKC & LXS196 & $\begin{array}{l}\text { Small-molecule } \\
\text { inhibitor for PKC }\end{array}$ & $\begin{array}{l}\text { Phase I } \\
\text { (NCT02601378) }\end{array}$ & $\begin{array}{l}\text { Single or } \\
\text { combinatory (with } \\
\text { HDM201) }\end{array}$ & $\begin{array}{l}\text { Active, not } \\
\text { recruiting }\end{array}$ & Metastatic uveal melanoma & - \\
\hline \multirow[t]{4}{*}{ JAK2 } & $\begin{array}{l}\text { Pacritinib } \\
\text { (SB1518) }\end{array}$ & $\begin{array}{l}\text { Macrocyclic } \\
\text { pyrimidine-based } \\
\text { JAK2 inhibitor }\end{array}$ & $\begin{array}{l}\text { Phase I } \\
\text { (NCT02342353) }\end{array}$ & $\begin{array}{l}\text { Combinatory (with } \\
\text { erlotinib) }\end{array}$ & $\begin{array}{l}\text { Terminated (drug } \\
\text { shortage) }\end{array}$ & EGFR-mutant NSCLC & Unposted \\
\hline & & & $\begin{array}{l}\text { Phase I } \\
\text { (NCT02323607) }\end{array}$ & $\begin{array}{l}\text { Combinatory (with } \\
\text { chemotherapy) }\end{array}$ & Completed & $\begin{array}{l}\text { Acute myeloid leukemia, FLT3 } \\
\text { mutations }\end{array}$ & Unposted \\
\hline & & & $\begin{array}{l}\text { Phase I } \\
\text { (NCT03601819) }\end{array}$ & Single & Recruiting & $\begin{array}{l}\text { Relapsed/refractory } \\
\text { lymphoproliferative disorders }\end{array}$ & - \\
\hline & & & $\begin{array}{l}\text { Phase II } \\
\text { (NCT02277093) }\end{array}$ & Single & $\begin{array}{l}\text { Terminated (FDA } \\
\text { issued a clinical } \\
\text { hold as pacritinib } \\
\text { had increased } \\
\text { side effects) }\end{array}$ & Refractory colorectal cancer & Posted \\
\hline
\end{tabular}


Table 1 continued

\begin{tabular}{|c|c|c|c|c|c|c|c|}
\hline Target & Drug & Strategy & Clinical trial & Treatment & Current status & Disease & Clinical results \\
\hline & & & $\begin{array}{l}\text { Phase I/II } \\
\text { (NCT00719836) }\end{array}$ & Single & Completed & $\begin{array}{l}\text { Advanced myeloid } \\
\text { malignancies }\end{array}$ & $\begin{array}{l}\text { Pacritinib showed clinical } \\
\text { activity in myelofibrosis with } \\
\text { tolerable side effects } \\
\text { }^{6} \text {. }\end{array}$ \\
\hline & & & $\begin{array}{l}\text { Phase II } \\
\text { (NCT02532010) }\end{array}$ & $\begin{array}{l}\text { Combinatory (with } \\
\text { decitabine or } \\
\text { cytarabine) }\end{array}$ & $\begin{array}{l}\text { Terminated } \\
\text { (initially by the } \\
\text { sponsor and later } \\
\text { due to financial } \\
\text { constraints) }\end{array}$ & $\begin{array}{l}\text { Older patients with acute } \\
\text { myeloid leukemia }\end{array}$ & Posted \\
\hline & \multirow[t]{11}{*}{ Ruxolitinib } & \multirow[t]{11}{*}{$\begin{array}{l}\text { Small-molecule } \\
\text { inhibitor of JAK1/2 }\end{array}$} & $\begin{array}{l}\text { Phase II } \\
\text { (NCT01877005) }\end{array}$ & Single & Completed & Hodgkin's lymphoma & Unposted \\
\hline & & & $\begin{array}{l}\text { Phase II } \\
\text { (NCT02876302) }\end{array}$ & $\begin{array}{l}\text { Combinatory (with } \\
\text { preoperative } \\
\text { chemotherapy) }\end{array}$ & Recruiting & $\begin{array}{l}\text { Triple-negative inflammatory } \\
\text { breast cancer }\end{array}$ & - \\
\hline & & & $\begin{array}{l}\text { Phase II } \\
\text { (NCT01423604) }\end{array}$ & $\begin{array}{l}\text { Combinatory (with } \\
\text { capecitabine) }\end{array}$ & Completed & Pancreatic cancer & $\begin{array}{l}\text { Treatment was generally well } \\
\text { tolerated and may have } \\
\text { improved survival in patients } \\
\text { with metastatic pancreatic } \\
\text { cancer with evidence of } \\
\text { systemic inflammation }^{87} \text {. }\end{array}$ \\
\hline & & & $\begin{array}{l}\text { Phase II } \\
\text { (NCT01594216) }\end{array}$ & $\begin{array}{l}\text { Combinatory (with } \\
\text { exemestane) }\end{array}$ & Completed & $\begin{array}{l}\text { Estrogen receptor-positive } \\
\text { breast cancer }\end{array}$ & Unposted \\
\hline & & & $\begin{array}{l}\text { Phase I/II } \\
\text { (NCT02066532) }\end{array}$ & $\begin{array}{l}\text { Combinatory (with } \\
\text { trastuzumab) }\end{array}$ & $\begin{array}{l}\text { Active, not } \\
\text { recruiting }\end{array}$ & $\begin{array}{l}\text { Metastatic HER2-positive } \\
\text { breast cancer }\end{array}$ & - \\
\hline & & & $\begin{array}{l}\text { Phase I/II } \\
\text { (NCT02041429) }\end{array}$ & $\begin{array}{l}\text { Combinatory (with } \\
\text { preoperative } \\
\text { chemotherapy) }\end{array}$ & $\begin{array}{l}\text { Active, not } \\
\text { recruiting }\end{array}$ & $\begin{array}{l}\text { Triple-negative inflammatory } \\
\text { breast cancer }\end{array}$ & - \\
\hline & & & $\begin{array}{l}\text { Phase II } \\
\text { (NCT03153982) }\end{array}$ & Single & Recruiting & $\begin{array}{l}\text { Operable head and } \\
\text { neck cancer }\end{array}$ & - \\
\hline & & & $\begin{array}{l}\text { Phase II } \\
\text { (NCT00674479) }\end{array}$ & Single & Completed & $\begin{array}{l}\text { Advanced hematologic } \\
\text { malignancies }\end{array}$ & Posted \\
\hline & & & $\begin{array}{l}\text { Phase I/II } \\
\text { (NCT02155465) }\end{array}$ & $\begin{array}{l}\text { Combinatory (with } \\
\text { erlotinib) }\end{array}$ & Completed & $\begin{array}{l}\text { EGFR-mutant lung } \\
\text { adenocarcinoma with } \\
\text { acquired resistance to } \\
\text { erlotinib }\end{array}$ & Posted \\
\hline & & & $\begin{array}{l}\text { Phase I } \\
\text { (NCT01702064) }\end{array}$ & $\begin{array}{l}\text { Combinatory (with } \\
\text { nilotinib) }\end{array}$ & Completed & Chronic myeloid leukemia & $\begin{array}{l}\text { The combinatory treatment } \\
\text { was safe and tolerable, and } \\
\text { the molecular responses were } \\
\text { encouraging }{ }^{88} \text {. }\end{array}$ \\
\hline & & & $\begin{array}{l}\text { Phase I/II } \\
\text { (NCT01751425) }\end{array}$ & $\begin{array}{l}\text { Combinatory (with } \\
\text { tyrosine kinase } \\
\text { inhibitors) }\end{array}$ & $\begin{array}{l}\text { Active, not } \\
\text { recruiting }\end{array}$ & $\begin{array}{l}\text { Chronic myeloid leukemia } \\
\text { with minimal residual disease } \\
\text { while on therapy with } \\
\text { tyrosine kinase inhibitors }\end{array}$ & $\begin{array}{l}\text { The combinatory treatment } \\
\text { was safe and tolerable. There } \\
\text { was no apparent clinical } \\
\text { benefit }{ }^{89} \text {. }\end{array}$ \\
\hline & \multirow[t]{2}{*}{ AZD1480 } & \multirow[t]{2}{*}{$\begin{array}{l}\text { ATP-competitive } \\
\text { inhibitor of JAK1 and } 2 \\
\text { kinases }\end{array}$} & $\begin{array}{l}\text { Phase I } \\
\text { (NCT01219543) }\end{array}$ & Single & $\begin{array}{l}\text { Terminated } \\
\text { (compound } \\
\text { development } \\
\text { discontinued) }\end{array}$ & $\begin{array}{l}\text { Solid tumors, advanced solid } \\
\text { malignancies, advanced } \\
\text { hepatocellular carcinoma, } \\
\text { EGFR- and/or ROS-mutant } \\
\text { non-small-cell lung cancer, } \\
\text { lung carcinoma metastasis, } \\
\text { gastric cancer }\end{array}$ & Unposted \\
\hline & & & $\begin{array}{l}\text { Phase I } \\
\text { (NCT01112397) }\end{array}$ & Single & $\begin{array}{l}\text { Terminated } \\
\text { (decision to stop } \\
\text { development of } \\
\text { AZD1480) }\end{array}$ & Solid tumors & Unposted \\
\hline \multirow[t]{6}{*}{ STAT3 } & WP1066 & $\begin{array}{l}\text { Dephosphorylation } \\
\text { and nuclear export of } \\
\text { constitutively } \\
\text { phosphorylated STAT3 }\end{array}$ & $\begin{array}{l}\text { Phase I } \\
\text { (NCT01904123) }\end{array}$ & Single & Recruiting & $\begin{array}{l}\text { Recurrent malignant glioma, } \\
\text { progressive metastatic } \\
\text { melanoma in the brain }\end{array}$ & - \\
\hline & \multirow[t]{4}{*}{ AZD9150 } & \multirow[t]{4}{*}{$\begin{array}{l}\text { STAT3 antisense } \\
\text { oligonucleotide }\end{array}$} & $\begin{array}{l}\text { Phase I } \\
\text { (NCT03527147) }\end{array}$ & $\begin{array}{l}\text { Combinatory (with } \\
\text { acalabrutinib) }\end{array}$ & Recruiting & $\begin{array}{l}\text { Relapsed/refractory } \\
\text { aggressive non-Hodgkin's } \\
\text { lymphoma }\end{array}$ & - \\
\hline & & & $\begin{array}{l}\text { Phase I/II } \\
\text { (NCT03421353) }\end{array}$ & $\begin{array}{l}\text { Combinatory (with } \\
\text { durvalumab or } \\
\text { chemotherapy) }\end{array}$ & $\begin{array}{l}\text { Active, not } \\
\text { recruiting }\end{array}$ & Advanced solid tumors & - \\
\hline & & & $\begin{array}{l}\text { Phase I/lb } \\
\text { (NCT01839604) }\end{array}$ & Single & Completed & $\begin{array}{l}\text { Advanced/metastatic } \\
\text { hepatocellular carcinoma }\end{array}$ & Posted \\
\hline & & & $\begin{array}{l}\text { Phase I/II } \\
\text { (NCT01563302) }\end{array}$ & Single & Completed & Advanced cancers & $\begin{array}{l}\text { AZD9150 was well tolerated } \\
\text { and showed efficacy in a } \\
\text { subset of heavily pretreated } \\
\text { patients with diffuse large B } \\
\text { cell lymphoma } 90\end{array}$ \\
\hline & OPB-51602 & & $\begin{array}{l}\text { Phase I } \\
\text { (NCT02058017) }\end{array}$ & Single & $\begin{array}{l}\text { Terminated } \\
\text { (because of }\end{array}$ & $\begin{array}{l}\text { Locally advanced } \\
\text { nasopharyngeal carcinoma }\end{array}$ & Unposted \\
\hline
\end{tabular}


Table 1 continued

\begin{tabular}{|c|c|c|c|c|c|c|c|}
\hline Target & Drug & Strategy & Clinical trial & Treatment & Current status & Disease & Clinical results \\
\hline & & $\begin{array}{l}\text { A small-molecule } \mathrm{SH} 2 \\
\text { domain-targeting } \\
\text { STAT3 inhibitor }\end{array}$ & & & $\begin{array}{l}\text { unbearable lactic } \\
\text { and metabolic } \\
\text { acidosis) }\end{array}$ & & \\
\hline & & & $\begin{array}{l}\text { Phase I } \\
\text { (NCT01423903) }\end{array}$ & Single & Completed & Advanced cancer & Unposted \\
\hline & & & $\begin{array}{l}\text { Phase I } \\
\text { (NCT01344876) }\end{array}$ & Single & Completed & Hematologic malignancies & $\begin{array}{l}\text { OPB-51602 was safe and well } \\
\text { tolerated. However, long-term } \\
\text { administration at higher doses } \\
\text { was difficult with the daily } \\
\text { dosing schedule, and no } \\
\text { response was seen }{ }^{91} \text {. }\end{array}$ \\
\hline & & & $\begin{array}{l}\text { Phase I } \\
\text { (NCT01184807) }\end{array}$ & Single & Completed & Advanced solid tumors & $\begin{array}{l}\text { OPB-51602 demonstrated } \\
\text { promising antitumor activity, } \\
\text { particularly in NSCLC. Less } \\
\text { frequent dosing should be } \\
\text { explored }^{92} \text {. }\end{array}$ \\
\hline \multirow[t]{9}{*}{$\operatorname{cox} 1 / 2$} & Sulindac & $\begin{array}{l}\text { Nonsteroidal anti- } \\
\text { inflammatory drug } \\
\text { (NSAID), arylalkanoic } \\
\text { acid derivative }\end{array}$ & $\begin{array}{l}\text { Phase III } \\
\text { (NCT00118365) }\end{array}$ & $\begin{array}{l}\text { Combinatory (with } \\
\text { eflornithine) }\end{array}$ & Completed & $\begin{array}{l}\text { Preventing colorectal cancer } \\
\text { with colon polyps }\end{array}$ & Posted \\
\hline & & & $\begin{array}{l}\text { Phase III } \\
\text { (NCT01349881) }\end{array}$ & $\begin{array}{l}\text { Single and } \\
\text { combinatory (with } \\
\text { eflornithine) }\end{array}$ & Recruiting & $\begin{array}{l}\text { Reducing the three-year } \\
\text { event rate of adenomas and } \\
\text { second primary colorectal } \\
\text { cancers in patients previously } \\
\text { treated for stages } 0 \text { through } \\
\text { III colon/rectal cancer }\end{array}$ & - \\
\hline & & & $\begin{array}{l}\text { Phase I } \\
\text { (NCT00245024) }\end{array}$ & Single & Completed & $\begin{array}{l}\text { Preventing breast cancer in } \\
\text { women at high risk of } \\
\text { breast cancer }\end{array}$ & Unposted \\
\hline & & & $\begin{array}{l}\text { Phase II } \\
\text { (NCT01856322) }\end{array}$ & Single & $\begin{array}{l}\text { Terminated (due } \\
\text { to lack of accrual) }\end{array}$ & Advanced colorectal cancer & - \\
\hline & & & $\begin{array}{l}\text { Phase II } \\
\text { (NCT00039520) }\end{array}$ & $\begin{array}{l}\text { Combinatory (with } \\
\text { docetaxel) }\end{array}$ & Completed & $\begin{array}{l}\text { Metastatic/recurrent } \\
\text { breast cancer }\end{array}$ & Unposted \\
\hline & & & $\begin{array}{l}\text { Phase II } \\
\text { (NCT00368927) }\end{array}$ & Single & Completed & $\begin{array}{l}\text { Preventing lung cancer in } \\
\text { current/former smokers with } \\
\text { bronchial dysplasia }\end{array}$ & $\begin{array}{l}\text { Sufficient benefits were not } \\
\text { observed }^{93} \text {. }\end{array}$ \\
\hline & Celecoxib & $\begin{array}{l}\text { a COX-2- } \\
\text { selective NSAID }\end{array}$ & $\begin{array}{l}\text { Phase II } \\
\text { (NCT01695226.) }\end{array}$ & Single & Completed & $\begin{array}{l}\text { Preoperative celecoxib } \\
\text { treatment in breast cancer }\end{array}$ & $\begin{array}{l}\text { Celecoxib induced } \\
\text { transcriptional programs } \\
\text { supporting antitumor } \\
\text { activity }{ }^{94} \text {. }\end{array}$ \\
\hline & & & $\begin{array}{l}\text { Phase III (NCT } \\
01041781)\end{array}$ & $\begin{array}{l}\text { Combinatory (with } \\
\text { gemcitabine, } \\
\text { pemetrexed } \\
\text { disodium and } \\
\text { carboplatin) }\end{array}$ & $\begin{array}{l}\text { Terminated } \\
\text { (recommended } \\
\text { by the Data and } \\
\text { Safety } \\
\text { Monitoring Board) }\end{array}$ & Advanced NSCLC & $\begin{array}{l}\text { A urinary metabolite of } \\
\text { prostaglandin E2 was able to } \\
\text { identify patients who could } \\
\text { benefit from COX2 } \\
\text { inhibition } 95 \text {. }\end{array}$ \\
\hline & & & $\begin{array}{l}\text { Phase III (NCT } \\
\text { 02429427) }\end{array}$ & Single & Completed & Primary breast cancer & $\begin{array}{l}\text { Clinical benefit was not } \\
\text { observed. Further studies } \\
\text { focusing on the ER }+ \\
\text { subpopulation are } \\
\text { ongoing }^{96,97} \text {. }\end{array}$ \\
\hline
\end{tabular}

investigation for cancer therapy or prevention as single or combinatory agents (Table 1). Although some of the trials have been terminated because of limited efficacy and intolerable side effects, some have shown promising clinical results, such as a significant trend toward improved disease-free survival and tumor reduction with minimal side effects. Therefore, further investigation into the microenvironmental cues that favor integrin and $\mathrm{p} 38^{\text {low }} /$ ERK $^{\text {high }}$ activity would broaden the current knowledge of DCC-reawakening factors.

\section{Acknowledgements}

This work was supported by the National Research Foundation of Korea (NRF) through a grant funded by the Korean government (MSIP: Ministry of Science,
ICT and Future Planning) (No. NRF-2017R1E1A1A01075125). Additionally, this work was supported by a grant from the Cell Logistics Research Center of the National Research Foundation of Korea (NRF-2016R1A5A1007318) and by a Gwangju Institute of Science and Technology (GIST) Research Institute (GRI) grant funded by the GIST in 2020.

\section{Conflict of interest}

The authors declare that they have no conflict of interest.

\section{Publisher's note}

Springer Nature remains neutral with regard to jurisdictional claims in published maps and institutional affiliations.

Received: 7 December 2019 Revised: 3 March 2020 Accepted: 19 March 2020.

Published online: 16 April 2020 


\section{References}

1. Valastyan, S. \& Weinberg, R. A. Tumor metastasis: molecular insights and evolving paradigms. Cell 147, 275-292 (2011)

2. Friedl, P. \& Alexander, S. Cancer invasion and the microenvironment: plasticity and reciprocity. Cell 147, 992-1009 (2011).

3. De Palma, M., Biziato, D. \& Petrova, T. V. Microenvironmental regulation of tumour angiogenesis. Nat. Rev. Cancer 17, 457 (2017).

4. Brown, J. A. et al. TGF- $\beta$-induced quiescence mediates chemoresistance of tumor-propagating cells in squamous cell carcinoma. Cell Stem Cell 21, 650-664 (2017). e658.

5. Gonzalez, H., Robles, I. \& Werb, Z. Innate and acquired immune surveillance in the postdissemination phase of metastasis. FEBS J. 285, 654-664 (2018).

6. Chambard, J.-C., Lefloch, R., Pouysségur, J. \& Lenormand, P. ERK implication in cell cycle regulation. Biochim. Biophys. Acta (BBA)-Mol. Cell Res. 1773 1299-1310 (2007).

7. Mebratu, Y. \& Tesfaigzi, Y. How ERK1/2 activation controls cell proliferation and cell death: Is subcellular localization the answer? Cell Cycle 8, 1168-1175 (2009).

8. Aguirre-Ghiso, J. A., Estrada, Y., Liu, D. \& Ossowski, L. ERKMAPK activity as a determinant of tumor growth and dormancy; regulation by p38SAPK. Cancer Res. 63, 1684-1695 (2003).

9. Dhillon, A. S., Hagan, S., Rath, O. \& Kolch, W. MAP kinase signalling pathways in cancer. Oncogene 26, 3279 (2007).

10. Zhang, W. \& Liu, H. T. MAPK signal pathways in the regulation of cell proliferation in mammalian cells. Cell Res. 12, 9 (2002).

11. Sosa, M. S., Avivar-Valderas, A., Bragado, P., Wen, H.C. \& Aguirre-Ghiso, J. A. ERK1/2 and $p 38 \mathrm{a} / \beta$ signaling in tumor cell quiescence: opportunities to control dormant residual disease. Clin. Cancer Res. 17, 5850-5857 (2011).

12. Bragado, P. et al. TGF- $\beta 2$ dictates disseminated tumour cell fate in target organs through TGF- $\beta-$ RIII and p38a/ $\beta$ signalling. Nat. Cell Biol. 15, 1351 (2013).

13. Prunier, C., Baker, D., ten Dijke, P. \& Ritsma, L. TGF- $\beta$ family signaling pathways in cellular dormancy. Trends Cancer 5, 66-78 (2018).

14. Liu, D., Ghiso, J. A. A., Estrada, Y. \& Ossowski, L. EGFR is a transducer of the urokinase receptor initiated signal that is required for in vivo growth of a human carcinoma. Cancer Cell 1, 445-457 (2002).

15. Mahmood, N., Mihalcioiu, C. \& Rabbani, S. A. Multifaceted role of the urokinase-type plasminogen activator (UPA) and its receptor (UPAR): diagnostic, prognostic, and therapeutic applications. Front. Oncol. 8, 24 (2018).

16. Aguirre-Ghiso, J. A., Liu, D., Mignatti, A., Kovalski, K. \& Ossowski, L. Urokinase receptor and fibronectin regulate the ERKMAPK to p38MAPK activity ratios that determine carcinoma cell proliferation or dormancy in vivo. Mol. Biol. cell 12, 863-879 (2001).

17. Heiss, M. M. et al. Individual development and UPA-receptor expression of disseminated tumour cells in bone marrow: a Reference to early systemic disease in solid cancer. Nat. Med. 1, 1035 (1995).

18. Adam, A. P. et al. Computational identification of a p38SAPK-regulated transcription factor network required for tumor cell quiescence. Cancer Res. 69 5664-5672 (2009)

19. Ranganathan, A. C., Zhang, L., Adam, A. P. \& Aguirre-Ghiso, J. A. Functional coupling of p38-induced up-regulation of BiP and activation of RNAdependent protein kinase-like endoplasmic reticulum kinase to drug resistance of dormant carcinoma cells. Cancer Res. 66, 1702-1711 (2006).

20. Schewe, D. M. \& Aguirre-Ghiso, J. A. ATF6a-Rheb-mTOR signaling promotes survival of dormant tumor cells in vivo. Proc. Natl Acad. Sci. 105, 10519-10524 (2008).

21. Cummings, C. T., DeRyckere, D., Earp, H. S. \& Graham, D. K. Molecular pathways: MERTK signaling in cancer. Clin. Cancer Res. 19, 5275-5280 (2013).

22. Shiozawa, Y., Pedersen, E. A. \& Taichman, R. S. GAS6/Mer axis regulates the homing and survival of the E2AVPBX1-positive B-cell precursor acute lymphoblastic leukemia in the bone marrow niche. Exp. Hematol. 38, 132-140 (2010).

23. Yumoto, $\mathrm{K}$. et al. Axl is required for TGF- 32 -induced dormancy of prostate cancer cells in the bone marrow. Sci. Rep. 6, 36520 (2016).

24. Kobayashi, A. et al. Bone morphogenetic protein 7 in dormancy and metastasis of prostate cancer stem-like cells in bone. J. Exp. Med. 208, 2641-2655 (2011).

25. Barkan, D. \& Chambers, A. F. B1-integrin: a potential therapeutic target in the battle against cancer recurrence. Clin. Cancer Res. 17, 7219-7223 (2011).

26. Barkan, D. et al. Inhibition of metastatic outgrowth from single dormant tumor cells by targeting the cytoskeleton. Cancer Res. 68, 6241-6250 (2008).

27. Barkan, D. et al. Metastatic growth from dormant cells induced by a colI-enriched fibrotic environment. Cancer Res. 70, 5706-5716 (2010).
28. Ghiso, J. A. A., Kovalski, K. \& Ossowski, L. Tumor dormancy induced by downregulation of urokinase receptor in human carcinoma involves integrin and MAPK signaling. J. Cell Biol. 147, 89-104 (1999).

29. Shibue, T. \& Weinberg, R. A. Integrin $\beta 1$-focal adhesion kinase signaling directs the proliferation of metastatic cancer cells disseminated in the lungs. Proc. Natl Acad. Sci. 106, 10290-10295 (2009).

30. Weaver, V. M. et al. Reversion of the malignant phenotype of human breast cells in three-dimensional culture and in vivo by integrin blocking antibodies. J. Cell Biol. 137, 231-245 (1997)

31. White, D. E. et al. Targeted disruption of $\beta 1$-integrin in a transgenic mouse model of human breast cancer reveals an essential role in mammary tumor induction. Cancer Cell 6, 159-170 (2004).

32. Boyerinas, B. et al. Adhesion to osteopontin in the bone marrow niche regulates lymphoblastic leukemia cell dormancy. Blood 121, 4821-4831 (2013).

33. Gao, $\mathrm{H}$. et al. Multi-organ site metastatic reactivation mediated by non-canonical discoidin domain receptor 1 signaling. Cell 166, 47-62 (2016).

34. Lecarpentier, Y., Schussler, O., HEBERT, J.-L. \& VALLEE, A. Multiple targets of the canonical WNT/beta-catenin signaling in cancers. Front. Oncol. 9, 1248 (2019).

35. Malladi, S. et al. Metastatic latency and immune evasion through autocrine inhibition of WNT. Cell 165, 45-60 (2016).

36. Yang, $\mathrm{H}$. et al. The role of cellular reactive oxygen species in cancer chemotherapy. J. Exp. Clin. Cancer Res. 37, 266 (2018).

37. Liou, G.-Y. \& Storz, P. Reactive oxygen species in cancer. Free Radic. Res. 44 479-496 (2010).

38. Teng, M. W., Swann, J. B., Koebel, C. M., Schreiber, R. D. \& Smyth, M. J. Immunemediated dormancy: an equilibrium with cancer. J. Leukoc. Biol. 84, 988-993 (2008).

39. Machida, $\mathrm{H}$. et al. Significance of monocyte counts at recurrence on survival outcome of women with endometrial cancer. Int. J. Gynecologic Cancer 27, 302-310 (2017)

40. Okubo, M. et al. M2-polarized macrophages contribute to neovasculogenesis, leading to relapse of oral cancer following radiation. Sci. Rep. $\mathbf{6}$, 27548 (2016).

41. Bowers, L. W. et al. NSAID use reduces breast cancer recurrence in overweight and obese women: role of prostaglandin-aromatase interactions. Cancer Res. 74, 4446-4457 (2014)

42. Hughes, R. et al. Perivascular M2 macrophages stimulate tumor relapse after chemotherapy. Cancer Res. 75, 3479-3491 (2015).

43. Hallermalm, K. et al. Modulation of the tumor cell phenotype by IFN- $\gamma$ results in resistance of uveal melanoma cells to granule-mediated lysis by cytotoxic lymphocytes. J. Immunol. 180, 3766-3774 (2008).

44. Namjoshi, P., Showalter, L., Czerniecki, B. J. \& Koski, G. K. T-helper 1-type cytokines induce apoptosis and loss of HER-family oncodriver expression in murine and human breast cancer cells. Oncotarget 10, 6006 (2019).

45. Payne, K. K. et al. Tumor-reactive immune cells protect against metastatic tumor and induce immunoediting of indolent but not quiescent tumor cells. J. Leukoc. Biol. 100, 625-635 (2016).

46. Kmieciak, M., Payne, K. K., Wang, X.-Y. \& Manjili, M. H. IFN- $\gamma$ Ra is a key determinant of CD8 $+T$ cell-mediated tumor elimination or tumor escape and relapse in FVB mouse. PLOS ONE 8, e82544 (2013).

47. Cole, S. W. Chronic inflammation and breast cancer recurrence. J. Clin. Oncol. 27, 3418 (2009)

48. Toiyama, $Y$. et al. C-reactive protein as predictor of recurrence in patients with rectal cancer undergoing chemoradiotherapy followed by surgery. Anticancer Res. 33, 5065-5074 (2013).

49. Shrotriya, S. et al. Serum C-reactive protein is an important and powerful prognostic biomarker in most adult solid tumors. PloS ONE 13, e0202555 (2018).

50. Duffy, S. A. et al. Interleukin-6 predicts recurrence and survival among head and neck cancer patients. Cancer: Interdisciplinary International. J. Am. Cancer Soc. 113, 750-757 (2008).

51. Manjili, M. H. The inherent premise of immunotherapy for cancer dormancy. Cancer Res. 74, 6745-6749 (2014).

52. Baxevanis, C. N. \& Perez, S. A. Cancer dormancy: a regulatory role for endogenous immunity in establishing and maintaining the tumor dormant state. Vaccines 3, 597-619 (2015).

53. Eyles, J. et al. Tumor cells disseminate early, but immunosurveillance limits metastatic outgrowth, in a mouse model of melanoma. J. Clin. Investig. 120 2030-2039 (2010) 
54. Rhim, A. D. et al. EMT and dissemination precede pancreatic tumor formation. Cell 148, 349-361 (2012).

55. Qian, B.-Z. et al. CCL2 recruits inflammatory monocytes to facilitate breasttumour metastasis. Nature 475, 222 (2011).

56. Doak, G. R., Schwertfeger, K. L. \& Wood, D. K. Distant relations: macrophage functions in the metastatic niche. Trends Cancer 4, 445-459 (2018).

57. Chen, Q., Zhang, X. H.F. \& Massagué, J. Macrophage binding to receptor VCAM-1 transmits survival signals in breast cancer cells that invade the lungs. Cancer Cell 20, 538-549 (2011).

58. Nielsen, S. R. et al. Macrophage-secreted granulin supports pancreatic cancer metastasis by inducing liver fibrosis. Nat. Cell Biol. 18, 549 (2016).

59. Linde, N., Fluegen, G. \& Aguirre-Ghiso, J. The relationship between dormant cancer cells and their microenvironment. Adv. Cancer Res. 132, 45-71 (2016).

60. Wang, $\mathrm{H}$. et al. Immune checkpoint blockade and CAR-T cell therapy in hematologic malignancies. J. Hematol. Oncol. 12, 59 (2019).

61. Lan, Q. et al. Type I interferon/RF7 axis instigates chemotherapy-induced immunological dormancy in breast cancer. Oncogene 38, 2814 (2019).

62. Albrengues, J. et al. Neutrophil extracellular traps produced during inflammation awaken dormant cancer cells in mice. Science 361, eaao4227 (2018).

63. Ranganathan, A. C., Adam, A. P., Zhang, L. \& Aguirre-Ghiso, J. A. Tumor cell dormancy induced by p38SAPK and ER-stress signaling: an adaptive advantage for metastatic cells? Cancer Biol. Ther. 5, 729-735 (2006).

64. Senft, D. \& Ze'ev, A. R. Adaptive stress responses during tumor metastasis and dormancy. Trends Cancer 2, 429-442 (2016).

65. Cianfrocca, M. et al. Phase 1 trial of the antiangiogenic peptide ATN-161 (AcPHSCN-NH 2), a beta integrin antagonist, in patients with solid tumours. Br. J. Cancer 94, 1621-1626 (2006).

66. Ricart, A. D. et al. Volociximab, a chimeric monoclonal antibody that specifically binds a5 $\beta 1$ integrin: a phase I, pharmacokinetic, and biological correlative study. Clin. Cancer Res. 14, 7924-7929 (2008).

67. Bell-McGuinn, K. M. et al. A phase II, single-arm study of the anti-a5 $\beta 1$ integrin antibody volociximab as monotherapy in patients with platinum-resistant advanced epithelial ovarian or primary peritoneal cancer. Gynecologic Oncol. 121, 273-279 (2011).

68. Mita, M. et al. Phase I study of E7820, an oral inhibitor of integrin a-2 expression with antiangiogenic properties, in patients with advanced malignancies. Clin. Cancer Res. 17, 193-200 (2011).

69. Kerklaan, B. M. et al. A phase I, dose escalation, pharmacodynamic, pharmacokinetic, and food-effect study of a 2 integrin inhibitor E7820 in patients with advanced solid tumors. Investigational N. Drugs 34, 329-337 (2016).

70. Sawyer, M. et al. Phase II study of E7820 in combination with cetuximab in subjects (pts) with metastatic and refractory colorectal cancer (CRC). J. Clin. Oncol. 28, 3537-3537 (2010).

71. Heidenreich, A. et al. A randomized, double-blind, multicenter, phase 2 study of a human monoclonal antibody to human av integrins (intetumumab) in combination with docetaxel and prednisone for the first-line treatment of patients with metastatic castration-resistant prostate cancer. Ann. Oncol. 24, 329-336 (2013).

72. O'day, S. et al. A randomised, phase II study of intetumumab, an anti-a vintegrin $\mathrm{mAb}$, alone and with dacarbazine in stage IV melanoma. Br. J. cancer 105, 346-352 (2011).

73. Tabernero, J. et al. Abstract C119: Investigation of the anti-angiogenic effects of abituzumab in patients with colorectal or ovarian cancer and liver metastases using dynamic contrast-enhanced magnetic resonance imaging (DCEMRI), AACR-NCI-EORTC. Int. Conf:: Mol. Targets Cancer Therapeut. 14, C119 (2015).

74. Elez, E. et al. Abituzumab combined with cetuximab plus irinotecan versus cetuximab plus irinotecan alone for patients with KRAS wild-type metastatic colorectal cancer: the randomised phase I/II POSEIDON trial. Ann. Oncol. 26, 132-140 (2015).

75. Hussain, M. et al. Differential effect on bone lesions of targeting integrins: randomized phase II trial of abituzumab in patients with metastatic castrationresistant prostate cancer. Clin. Cancer Res. 22, 3192-3200 (2016).

76. Hersey, P. et al. A phase II, randomized, open-label study evaluating the antitumor activity of MEDI-522, a humanized monoclonal antibody directed against the human alpha $\vee$ beta 3 (avb3) integrin, \pm dacarbazine (DTIC) in patients with metastatic melanoma (MM). J. Clin. Oncol. 23, 7507-7507 (2005).

77. Rosenthal, M. A. et al. Evaluation of the safety, pharmacokinetics and treatment effects of an av $\beta 3$ integrin inhibitor on bone turnover and disease activity in men with hormone-refractory prostate cancer and bone metastases. Asia-Pac. J. Clin. Oncol. 6, 42-48 (2010).

78. Alva, A. et al. Phase II study of cilengitide (EMD 121974, NSC 707544) in patients with non-metastatic castration resistant prostate cancer, NCl-6735. A study by the DOD/PCF prostate cancer clinical trials consortium. Investigational N. Drugs 30, 749-757 (2012)

79. Heinemann, V. et al. Phase II randomised proof-of-concept study of the urokinase inhibitor upamostat (WX-671) in combination with gemcitabine compared with gemcitabine alone in patients with non-resectable, locally advanced pancreatic cancer. Br. J. Cancer 108, 766-770 (2013).

80. Mak, G. et al. A phase Ib dose-finding, pharmacokinetic study of the focal adhesion kinase inhibitor GSK2256098 and trametinib in patients with advanced solid tumours. Br. J. Cancer 120, 975-981 (2019).

81. Soria, J.-C. et al. A phase I, pharmacokinetic and pharmacodynamic study of GSK2256098, a focal adhesion kinase inhibitor, in patients with advanced solid tumors. Ann. Oncol. 27, 2268-2274 (2016).

82. Aung, K. L. et al. A phase II trial of GSK2256098 and trametinib in patients with advanced pancreatic ductal adenocarcinoma (PDAC) (MOBILITY-002 Trial, NCT02428270). J. Clin. Oncol. 36, 409 (2018).

83. Jones, S. F. et al. A phase I study of VS-6063, a second-generation focal adhesion kinase inhibitor, in patients with advanced solid tumors. Investigational N. drugs 33, 1100-1107 (2015).

84. Patel, M. R. et al. Phase $1 / 1$ b study of the FAK inhibitor defactinib (VS-6063) in combination with weekly paclitaxel for advanced ovarian cancer. J. Clin. Oncol. 32, 5521 (2017).

85. Gerber, D. E. et al. Phase 2 study of the focal adhesion kinase inhibitor defactinib (VS-6063) in previously treated advanced KRAS mutant non-small cell lung cancer. Lung Cancer 139, 60-67 (2020).

86. Verstovsek, S. et al. Phase 1/2 study of pacritinib, a next generation JAK2/FLT3 inhibitor, in myelofibrosis or other myeloid malignancies. J. Hematol. Oncol. 9 , 137 (2016).

87. Hurwitz, H. I. et al. Randomized, double-blind, phase II study of ruxolitinib or placebo in combination with capecitabine in patients with metastatic pancreatic cancer for whom therapy with gemcitabine has failed. J. Clin. Oncol. 33, 4039 (2015).

88. Sweet, K. et al. A phase I clinical trial of ruxolitinib in combination with nilotinib in chronic myeloid leukemia patients with molecular evidence of disease. Leuk. Res. 74, 89-96 (2018).

89. Guerra, V. A. et al. A phase I-II study of ruxolitinib (INCB18424) for patients with chronic myeloid leukemia with minimal residual disease while on therapy with imatinib. Blood 134, 5906 (2019).

90. Reilley, M. J. et al. STAT3 antisense oligonucleotide AZD9150 in a subset of patients with heavily pretreated lymphoma: results of a phase $1 \mathrm{~b}$ trial. $J$. Immunother. Cancer 6, 1-10 (2018).

91. Ogura, M. et al. Phase I study of OPB-51602, an oral inhibitor of signal transducer and activator of transcription 3, in patients with relapsed/ refractory hematological malignancies. Cancer Sci. 106, 896-901 (2015).

92. Wong, A. et al. Phase I and biomarker study of OPB-51602, a novel signal transducer and activator of transcription (STAT) 3 inhibitor, in patients with refractory solid malignancies. Ann. Oncol. 26, 998-1005 (2015).

93. Limburg, P. J. et al. Randomized phase ॥ trial of sulindac for lung cancer chemoprevention. Lung Cancer 79, 254-261 (2013).

94. Chen, E. Y. et al. A phase II study of celecoxib with irinotecan, 5fluorouracil, and leucovorin in patients with previously untreated advanced or metastatic colorectal cancer. Am. J. Clin. Oncol. 41, 1193-1198 (2018).

95. Edelman, M. J. et al. Phase III randomized, placebo-controlled, double-blind trial of celecoxib in addition to standard chemotherapy for advanced non-small-cell lung cancer with cyclooxygenase-2 overexpression: CALGB 30801 (Alliance). J. Clin. Oncol. 35, 2184 (2017).

96. Coombes, R. et al. A phase III, multicenter, double-blind, randomized trial of celecoxib versus placebo in primary breast cancer patients: Randomized European Celecoxib Trial (REACT). J. Clin. Oncol. 29 TPS115-TPS115 (2011).

97. Coombes, R. et al. Abstract GS3-03: A phase III multicentre double blind randomised trial of celecoxib versus placebo in primary breast cancer patients (REACT - Randomised EuropeAn celecoxib trial). Cancer Res. 78, GS3-03 (2018). 